\title{
"Pandemic as an accelerator of digital transformation in the insurance industry: evidence from Ukraine"
}

\begin{tabular}{|c|c|}
\hline \multirow{6}{*}{ AUTHORS } & Oleksandra Shevchuk iD http://orcid.org/0000-0002-2886-6311 \\
\hline & R https://publons.com/researcher/1817997/oleksandra-shevchuk/ \\
\hline & Iryna Kondrat iD http://orcid.org/0000-0001-7401-3128 \\
\hline & R https://publons.com/researcher/2032057/iryna-kondrat/ \\
\hline & Jolanta Stanienda (D http://orcid.org/0000-0002-9219-9461 \\
\hline & R https://publons.com/researcher/1832410/jolanta-stanienda/ \\
\hline ARTICLE INFO & $\begin{array}{l}\text { Oleksandra Shevchuk, Iryna Kondrat and Jolanta Stanienda (2020). Pandemic } \\
\text { as an accelerator of digital transformation in the insurance industry: evidence } \\
\text { from Ukraine. Insurance Markets and Companies, 11(1), 30-41. } \\
\text { doi:10.21511/ins.11(1).2020.04 }\end{array}$ \\
\hline DOI & http://dx.doi.org/10.21511/ins.11(1).2020.04 \\
\hline RELEASED ON & Wednesday, 23 December 2020 \\
\hline RECEIVED ON & Saturday, 19 September 2020 \\
\hline \multirow[t]{2}{*}{ ACCEPTED ON } & Sunday, 20 December 2020 \\
\hline & $(\mathrm{sc}) \overline{\mathrm{EY}}$ \\
\hline LICENSE & $\begin{array}{l}\text { This work is licensed under a Creative Commons Attribution } 4.0 \text { International } \\
\text { License }\end{array}$ \\
\hline JOURNAL & "Insurance Markets and Companies" \\
\hline ISSN PRINT & $2616-3551$ \\
\hline ISSN ONLINE & $2522-9591$ \\
\hline PUBLISHER & LLC "Consulting Publishing Company "Business Perspectives" \\
\hline FOUNDER & LLC "Consulting Publishing Company "Business Perspectives" \\
\hline
\end{tabular}

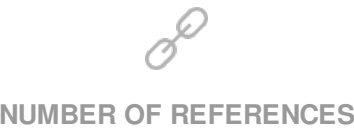

33
NUMBER OF FIGURES

7

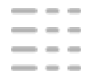

NUMBER OF TABLES

1

(C) The author(s) 2022. This publication is an open access article. 


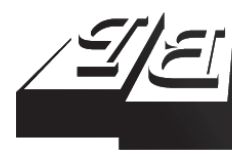

BUSINESS PERSPECTIVES

(O)

LLC "CPC "Business Perspectives" Hryhorii Skovoroda lane, 10, Sumy, 40022, Ukraine www.businessperspectives.org
Received on: $19^{\text {th }}$ of September, 2020 Accepted on: $20^{\text {th }}$ of December, 2020 Published on: $23^{\text {rd }}$ of December, 2020

(C) Oleksandra Shevchuk, Iryna Kondrat, Jolanta Stanienda, 2020

Oleksandra Shevchuk, Ph.D. in Economics, Department of Finance, Lviv Polytechnic National University, Ukraine. (Corresponding author)

Iryna Kondrat, Ph.D. in Economics, Department of Finance, Lviv Polytechnic National University, Ukraine.

Jolanta Stanienda, Ph.D. in Economics, Department of Risk Management and Insurance, Cracow University of Economics, Poland.
Oleksandra Shevchuk (Ukraine), Iryna Kondrat (Ukraine), Jolanta Stanienda (Poland)

\section{PANDEMIC AS AN ACCELERATOR OF DIGITAL TRANSFORMATION IN THE INSURANCE INDUSTRY: EVIDENCE FROM UKRAINE}

\begin{abstract}
Pandemic affects insurance industry both directly, via health shocks, and indirectly, via financial shocks, as well as via shift in the policyholder behavior and distribution channels. The paper contributes to understanding the impact of COVID-19 on the global and Ukrainian insurance market, provides insights into implementing digital measures and technologies for insurers, in response to changes caused or accelerated by pandemic, building the capabilities to survive and exploit the changing market.

A research of the the dynamics of Ukrainian insurance market changes during the quarantine period was conducted, the main tech achievements of leading insurers were investigated. The paper highlights priorities that insurers need to address in the wake of pandemic (distribution destruction, reinvention of the customer experience, cost structure changes, new protection offerings and new revenue pools), deals with different business strategies that insurers can follow to adopt and pivot in the lowtouch economy and reveals new opportunities to extend insurers' protection offerings and establish new sources of revenue emerged with digital transformation.
\end{abstract}

\section{Keywords}

insurance, COVID-19, digitalization, business strategies, innovation

\section{JEL Classification G01, G22}

\section{INTRODUCTION}

For the insurance industry, pandemic underwriting losses will end up costing around $\$ 107$ billion, corresponding to the disastrous years of 2017 and 2005. However, they were geographically limited events occurring over hours and days, which was very different from the global systemic and long-term impact of the COVID-19 pandemic.

The sudden stop of economic activity around the globe will batter insurance demand, too: global premium income is expected to shrink by $-3.8 \%$ in 2020 (life: $-4.4 \%, P \& C:-2.9 \%$ ), three times the pace witnessed during the global financial crisis (Allianz, 2020). To adopt and strive in new conditions of low-touch economy it's extremely important to identify key changes in the insurance industry due to pandemic, and to reveal the possibilities of digital technologies in improving the effectiveness of the insurance business model.

In the longer run a rather conservative insurance industry will come under increasing pressure - from clients, policymakers and regulators - that forms conditions and, at the same time, accelerates digital transformation and emergence of various innovations that enable to meet the dynamic customers' needs and increase the efficiency and competitiveness of insurance providers. 
Thus, the paper aims to analyse and assess the impact of the pandemic on the Ukrainian insurance market in order to provide insights into implementing and embedding digital measures and technologies for insurance providers, shaping the response to changes caused or accelerated by pandemic, building the capabilities to survive and exploit the changing market.

\section{LITERATURE REVIEW}

The impact of shutdown measures on the global economy and the insurance market in particular requires an in-depth study and assessment. However, it is already clear that it is unprecedented. Pandemic is resulting in a deep global economic contraction (Danylyshyn, 2020; Polinkevych et al., 2020). The downturn is affecting both the demand and supply of goods and services, capital and remittance flows in low- and middle-income countries like Ukraine, oil and commodity prices. According to World Bank forecasts, economies are expected to contract on average by -6.7 percent in per capita terms in 2020. The economic shock in 2020 is likely to be more severe than those that occurred during the 2007-2009 Global Financial Crisis. Therefore, financial security issues should be given increased attention both at the level of the individual institution and at the regional, sectoral and national levels (Shkolnyk et al., 2020). Unemployment, poverty, and income inequality rates are projected to rise across the region as well as globally (Tandon et al., 2020; Baber, 2020).

The financial sector can reduce the impact of COVID-19 on the real economy by providing bridge financing and restructuring of loans for viable enterprises. Medium and small enterprises need to be supported through special credit lines, reduced interest rates on loans, deferred repayments and partial credit guarantees to boost investment (Oliinyk \& Kozmenko, 2019). Digital transformation needs to take place at a faster rate to improve intelligent risk control systems (Vnukova et al., 2020; Wu \& Olson, 2020) as well as building a strategy for the development of companies taking into account the requirements of the concept of social responsibility (Glonti et al., 2020). A pandemic eruption can prompt a negative trend in investors' sentiment that strongly affects their financing decisions and impacts stock market prices (Siddiqui et al., 2020). Ding et al. (2020) researched that an aver- age increase in COVID19 over two months has resulted in a 12 percent drop in the stock prices all over the world.

COVID-19 affects insurers both directly, via health shocks (increases in mortality and morbidity), and indirectly, via financial shocks (lower equity prices, higher credit spreads, widespread downgrades, and lower short-term and long-term interest rate) $(\mathrm{PwC}, 2020)$ as well as via shift in the policyholder behaviour and distribution channels (Gasc, 2020). The financial impact of recent epidemics has been far larger than the direct health impact. Widespread asset-rating downgrades and persistently low interest rates would add to the difficult environment (Kirti \& Shin, 2020).

Property and casualty insurers provide protection against losses of property and business interruption, typically via short-term contracts (Vinogradova et al., 2019). Consequently, they hold a larger share of assets than life insurers in equities and are likely to be affected by stock market turmoil. Property \& casualty claims would be immaterial compared to financial market losses due to underwriting principles which limit or exclude pandemic risks. Operational resilience during a pandemic would be effectively ensured through normal business continuity management activities, ensuring remote working and access by customers, distributors and staff (Richter \& Wilson, 2020).

Insurers should also adapt to working from remote locations (Mey \& Ridder, 2020) enhanced their IT (Matteis, 2018; EIS, 2020) as well as security protocols (Kaigorodova et al., 2020). They should enable and equip company staff from actuaries, underwriters and claim managers to work offsite (Babuna et al., 2020; Cappiello, 2020; Mustafina et al., 2020) emphasized that the digital transformation is greatly affecting the insurance industry and forcing radical change upon corporate culture, products and processes (Lutsyshyn et al., 2019), customer relationship and relations with 
the sector's various competitors (Yehorycheva et al., 2020).

It is evidenced from the crisis that insurers, after focusing on surviving the initial shock of the economic hit and working remotely, are determining how to operate their business in the new normal using emerged opportunities.

\section{GENERALIZATION OF THE MAIN STATEMENTS}

Analysis of changes in the insurance market allows highlighting some of the priorities that insurers need to address in the wake of pandemic:

- Digital transformation is no longer an option. Despite budget constraints, insurance providers should take a hard look at their investment priorities in order to determine whether they invest more in product development or rather digitize their sales, support or claims handling. Consumers who have switched to using the online facilities during quarantine restrictions, are unlikely to return to their previous habits. Far-sighted insurers will gain a lead on their competitors by exploring and testing all sorts of creative possibilities that capitalize on this shift to the virtual world.

- Distribution destruction. Mobility and social networking have changed the vision, according to which the insurance market has been dominated by intermediaries who have played the role of understanding consumer and business needs, and then matching and tailoring insurance products and solutions to their needs. Pandemic accelerated the trend of making interactions between insurer and its customer simple, prompt, transparent and convenient, leading to a situation where customers will be more willing to buy direct using their online and offline 'trust' network to guide their choice.

- Reinvent the customer experience. Because of a shift in customer behavior, greater use of artificial intelligence and smart automation technologies will enable insurers to provide customers with exceptional experiences, to advance from using technology for transaction processing to decision-making. Therefore, developed market insurers will focus on creating value-added loss control and risk management services.

The pandemic has given insurers an opportunity to draw closer to their customers to help them mitigate economic hardship, to look for "trust multiplier actions", such as providing proactive advice and guidance, because the erosion of confidence will make trust even more important.

- Changing cost structures by introducing "flexing" workforces, improving IT efficiency and migrating to cloud services.

- New protection offerings and new revenue pools. Many new risk-management needs have emerged as a result of the pandemic. They include business continuity cover for small and medium-sized enterprises, pandemic insurance and event-cancellation policies. The growth in ecommerce and delivery services also offers insurers significant opportunities to extend their protection offerings and establish new sources of revenue.

Insurers who fail to keep pace with this increasing digitalization might be forced to exit markets in certain coverage lines.

Ukrainian insurance market has been growing during last decade except for falls in 2008 (global financial crisis), 2014-2015 (the beginning of war and occupation in eastern and southern Ukraine). However, the incentives for this growth were ambiguous, operating conditions were not always transparent, and "added value" for the consumer was not always obvious. If we analyze the premiums denominated in US dollars, we will feel the depth of the fall in $2008(-42 \%)$ and 2014-2015 $(-60 \%)$ as well as the real growth rate of the market that will differ from the nominal.

As can be seen from Figure 1, the insurers in Ukraine approached the current crisis better prepared than the crises of 2008or 2014-2015. Though the number of operating insurers continues to 


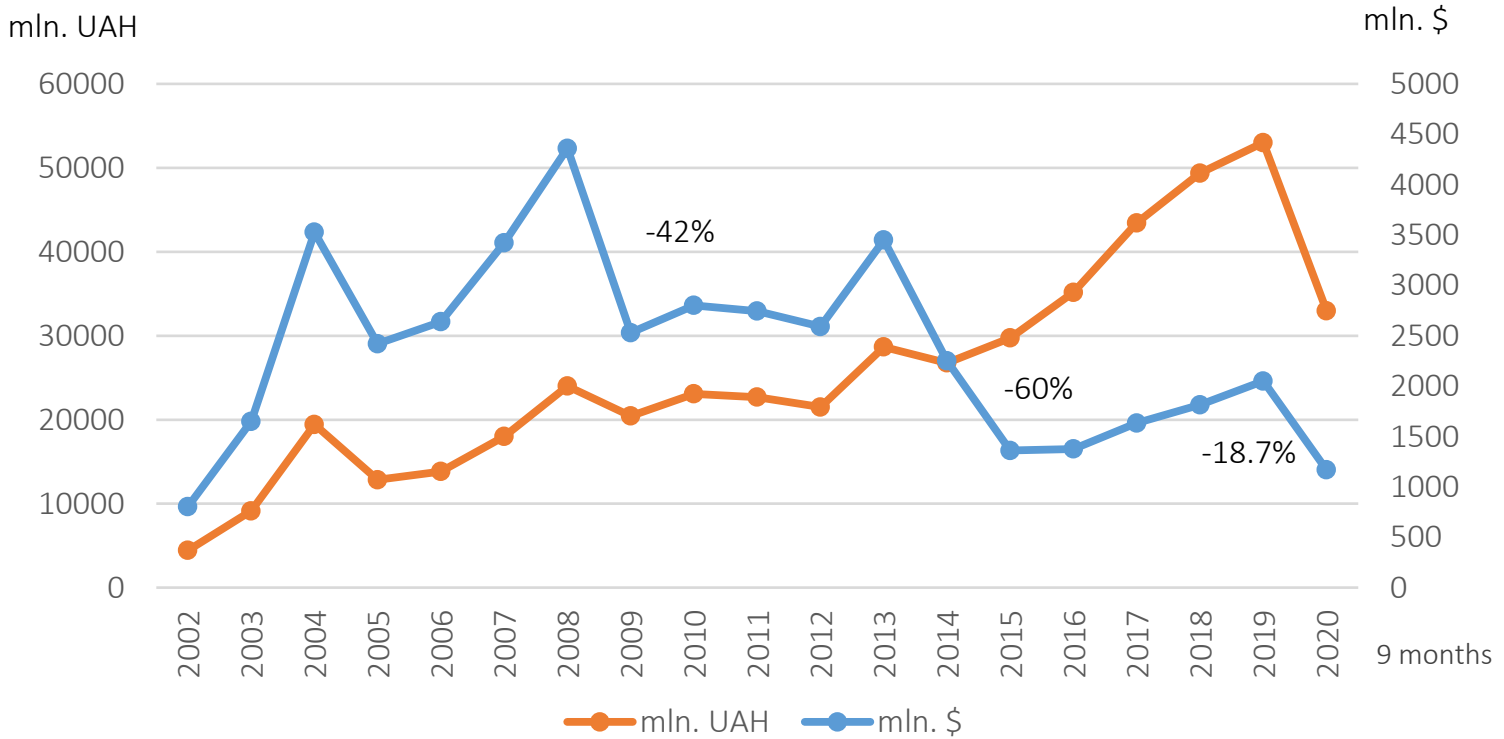

Figure 1. Dynamics of gross insurance premiums in Ukraine over the period of 2002-2020

decline (-26 companies in 2020), mainly due to the voluntary revocation of licenses, but it doesn't lead to a significant (proportional) reduction in the total assets of insurers. Over the last 7 years, the number of insurance companies has almost halved, but the size of their total assets has hardly changed. This indicates a high concentration of the market and a large number of "dormant inactive companies" with unsatisfactory assets quality. Correlation and regression analysis show that in Ukraine only $31 \%$ of total assets variance can be explained by the variance of the insurers number. Since the beginning of 2020, total assets have decreased by $4.6 \%$ and at the end of the third quarter amounted to UAH 61.6 billion (Figure 2).
Thanks to quarantine, the long-awaited market cleaning will be much faster. That is related to both the current solvency requirements, and a fact that owners get rid of assets that do not bring income, but require recapitalization, which is also exacerbated by the transition of regulatory and supervision functions to National Bank of Ukraine. Obviously, the trend of market consolidation and purification will continue due to the fact that, given pandemic restrictions, not all insurers were able to organize quality online services and afford technologies implementation.

In conditions of quarantine restrictions and a decline in economic activity, Ukrainian insurers that

Source: National Bank of Ukraine (2020a), Forinsurer (2020b).

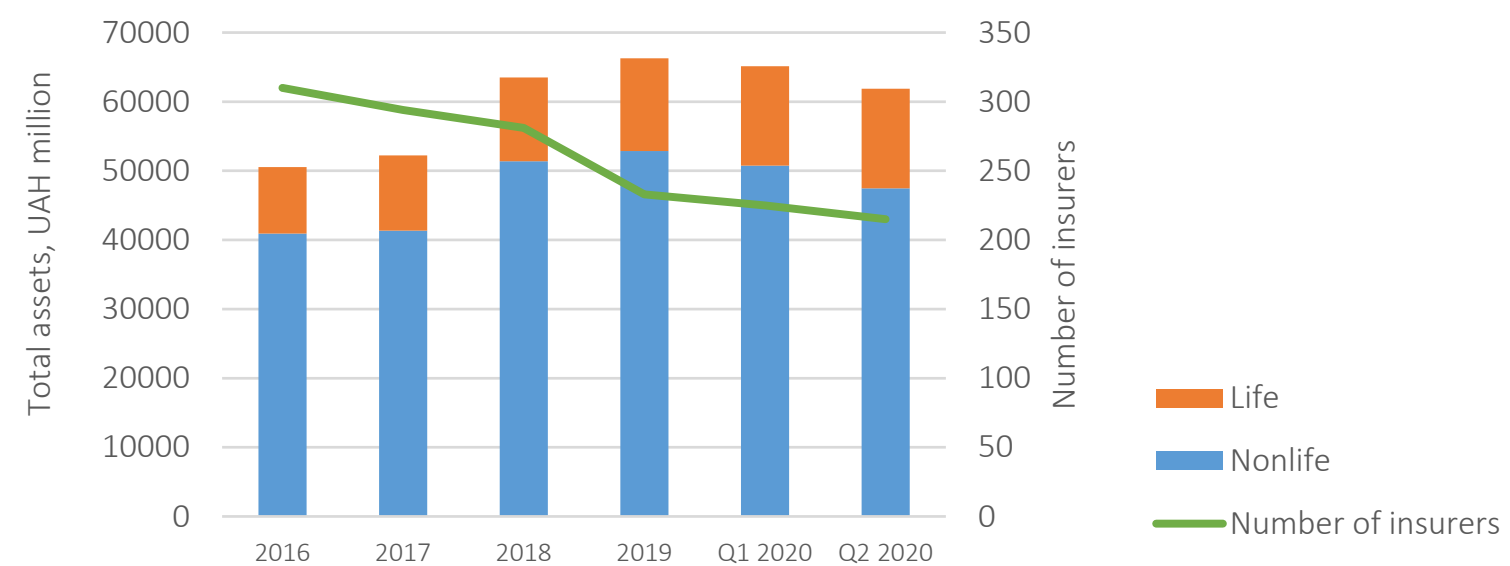

Figure 2. Number of insurers and volume of their total assets (billion UAH) in Ukraine over the period of 2016-2020 
Table 1. Ukrainian insurance market concentration in terms of gross premium in the first half of 2019-2020

\begin{tabular}{|c|c|c|c|c|}
\hline \multirow{2}{*}{$\begin{array}{c}\text { Top } \\
\text { insurers }\end{array}$} & \multicolumn{2}{|c|}{ Life insurance } & \multicolumn{2}{|c|}{ Nonlife insurance } \\
\hline & $\begin{array}{c}\text { Market share in the first } \\
\text { half of } 2019\end{array}$ & $\begin{array}{c}\text { Market share in the first } \\
\text { half of } 2020\end{array}$ & $\begin{array}{c}\text { Market share in the first } \\
\text { half of } 2019\end{array}$ & $\begin{array}{c}\text { Market share in the first } \\
\text { half of } 2020\end{array}$ \\
\hline Top 3 & $59.2 \%$ & $57 \%$ & $14.8 \%$ & $18 \%$ \\
\hline Top 5 & $90 \%$ & $77 \%$ & $24.5 \%$ & $27 \%$ \\
\hline Top 10 & $96.5 \%$ & $97 \%$ & $37.9 \%$ & $43 \%$ \\
\hline Top 20 & $100 \%$ & $100 \%$ & $59.4 \%$ & $65 \%$ \\
\hline Top 50 & - & - & $88.3 \%$ & $90 \%$ \\
\hline Top 100 & - & - & $98.2 \%$ & $99 \%$ \\
\hline Total & $100 \%$ & $100 \%$ & $100 \%$ & $100 \%$ \\
\hline
\end{tabular}

filed reports showed an increase in gross insurance premiums $(+4.4 \%$ for general insurance and $+10 \%$ for life insurance) in the first half of 2020 . It leads to a further increase of Ukrainian insurance market concentration, stimulated by the pandemic: insurers that were well advanced with digital transformation responded to the pandemic with greater speed and agility than their more cautious competitors. Thus, even during the "quarantine" first half of 2020, the life insurance sector grew by $10 \%$ and the market leader MetLife was largely a growth driver: as in the previous pre-crisis year, its premiums grew by $24 \%$. Shares of non-life insurance market leaders in total premiums also increased in the first half of 2020, raising market concentration by an average of 5\% mainly due to companies with TOP 10 (Table 1). As a result, there is rather big market, but little trust.
Despite the fact that 9 months of 2020 Ukrainian insurers ended with a profit of UAH 2.8 billion, their operational efficiency remains extremely low, combined ratio exceeds $100 \%$ because of high level of expenses, others than insurance payments and reserves cost. Expenses remain almost stable throughout the year - up to $56 \%$ of insurance premiums adjusted on the unearned premiums reserve. That can be changed primarily through technologies and digitization. Increased investment in direct online channels moves cost structures towards a larger upfront fixed cost, but a lower ongoing variable cost (provided the insurer achieves the desired scale), which is opposite to a traditional commission-based variable cost model for sales.

In 2020 the pandemic led to a decrease in the number of insurance policies by a quarter $(-25.9 \%)$

Source: Built by the authors using data from the National Bank of Ukraine (2020b), Forinsurer, 2020b).

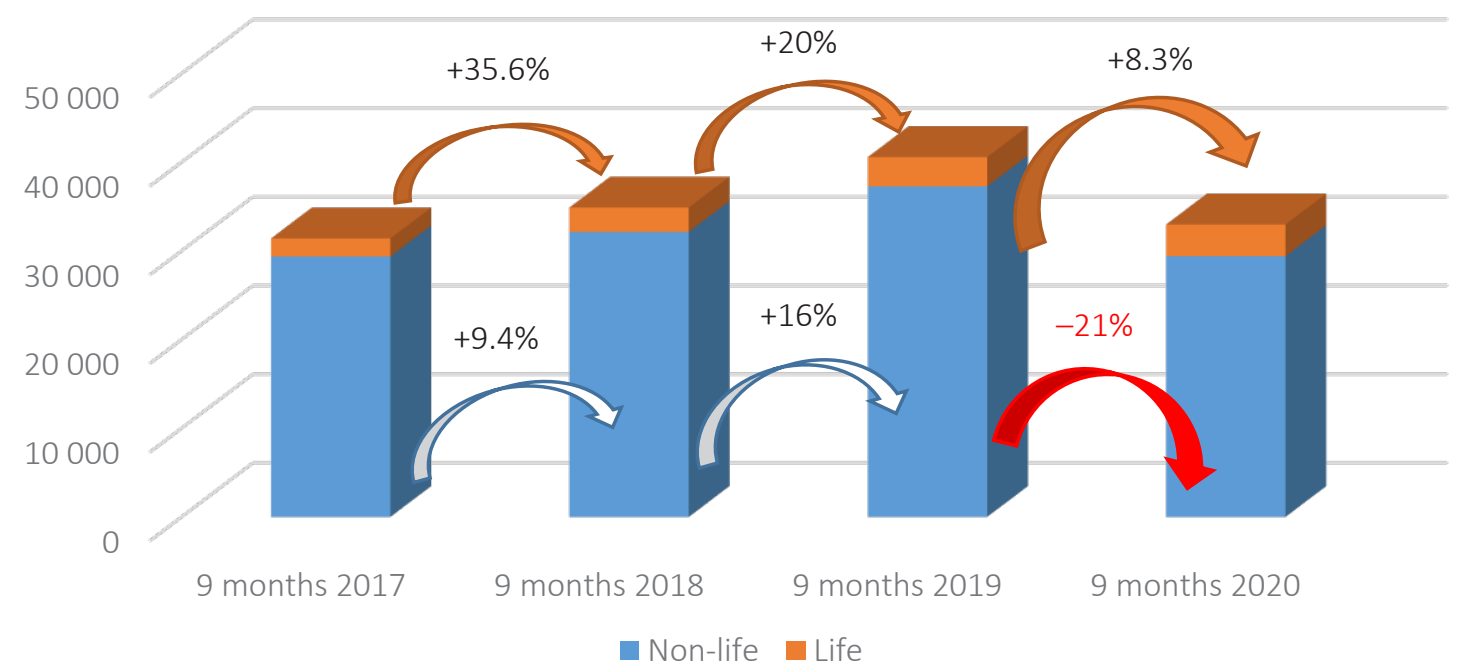

Figure 3. Dynamics of gross insurance premiums in Ukraine for 9 months 2017-2020, thousands UAH 


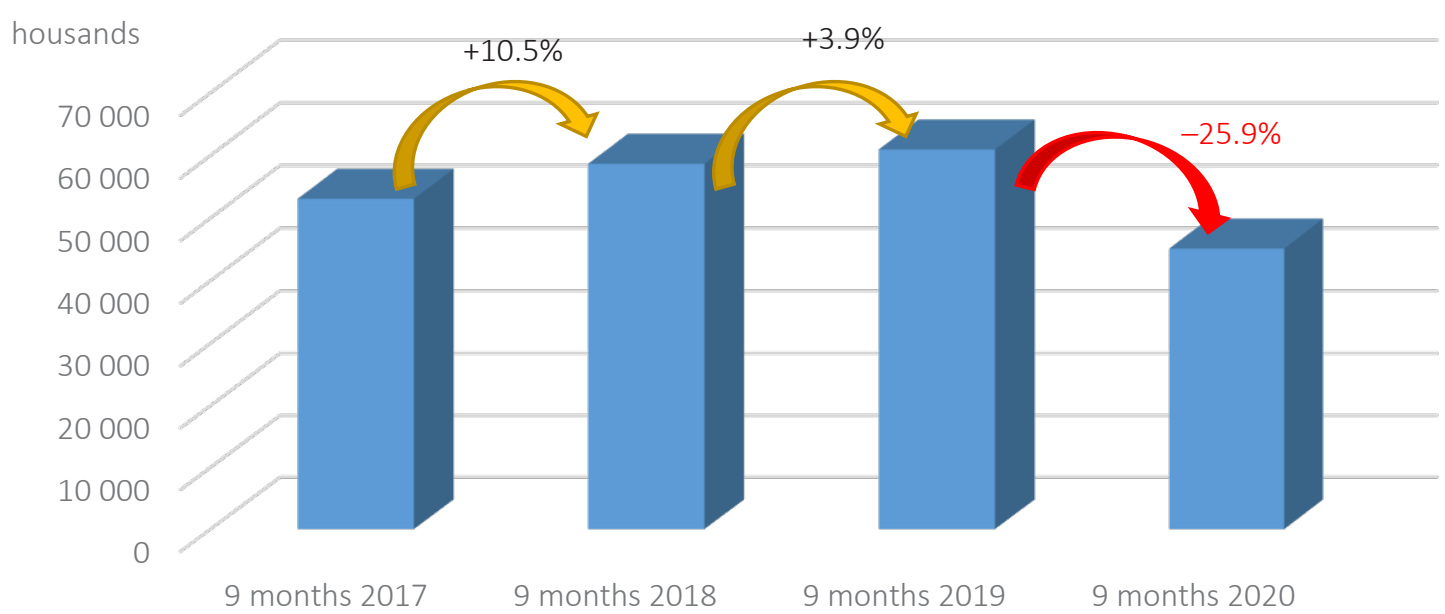

Figure 4. Dynamics of insurance policies number for 9 months 2017-2020

compared to the same period last year, a drop in gross premiums in the general insurance segment $(-21 \%)$ and increase in loss ratio of non-life insurance from $27 \%$ to $41 \%$ during 9 months of 2020 (Figures 3, 4).

At the same time, premiums in the life insurance segment increased by $8 \%$ (Figure 3 ). When all business communications have gone online, it seemed that the basis of life assurance was lost, because personal contact with the client deemed to be the heart of life business model. Working remotely, intermediaries had to master new tools and skills, which have benefitted them more than the usual methods. And it turned out the quarantine situation didn't interfere, but rather help insurers work with people's beliefs. We have seen a huge surge of interest in health programs. Another trend - the growing interest in personal savings, protection of personal capital, tools to reduce financial risks - will be an important catalyst of life insurance development for the next 2-3 years.

The current situation and incumbent technological innovations push the insurance industry in Ukraine to speed up the adoption of new tech across their ecosystems. Among the main achievements of leading insurers for the latest period are:

1. Electronic document management - greatly facilitated interaction with the client and reduces procedural moments of the company, noticeable saving time for both employees and customers.
2. Qualified electronic digital signature - can be used by both business partners and customers on any external platform.

3. Online sales and remote services. Insurers are implementing online customer identification procedures. The market shows a significant increase in online sales and the transition to the e-policy model in almost all types of insurance. The amount of insurance premiums under electronic contracts is UAH 1.12 billion for 9 months of 2020 (288\% more than for the same period in 2019) (Figure 5).

4. Mobile applications - contain information about insurance contracts purchased online, enable the customer to communicate with the company, add and remove contracts, add family members, etc.

5. Online services for car insurance purchasing based on "pay as you go" principle with payment for kilometres (Easy Katka from "Arsenal Insurance", Kasko2GO from "Universalna") and "pay how you drive" principle (Smart Drive from "ARX"). Insurers have created applications allowing drivers to control driving style, get useful advice on how to improve it, and get a discount for careful driving.

The next goal - to enable clients to go through the settlement process completely independently and remotely; track the status of process online and promptly receive payment from the company. 


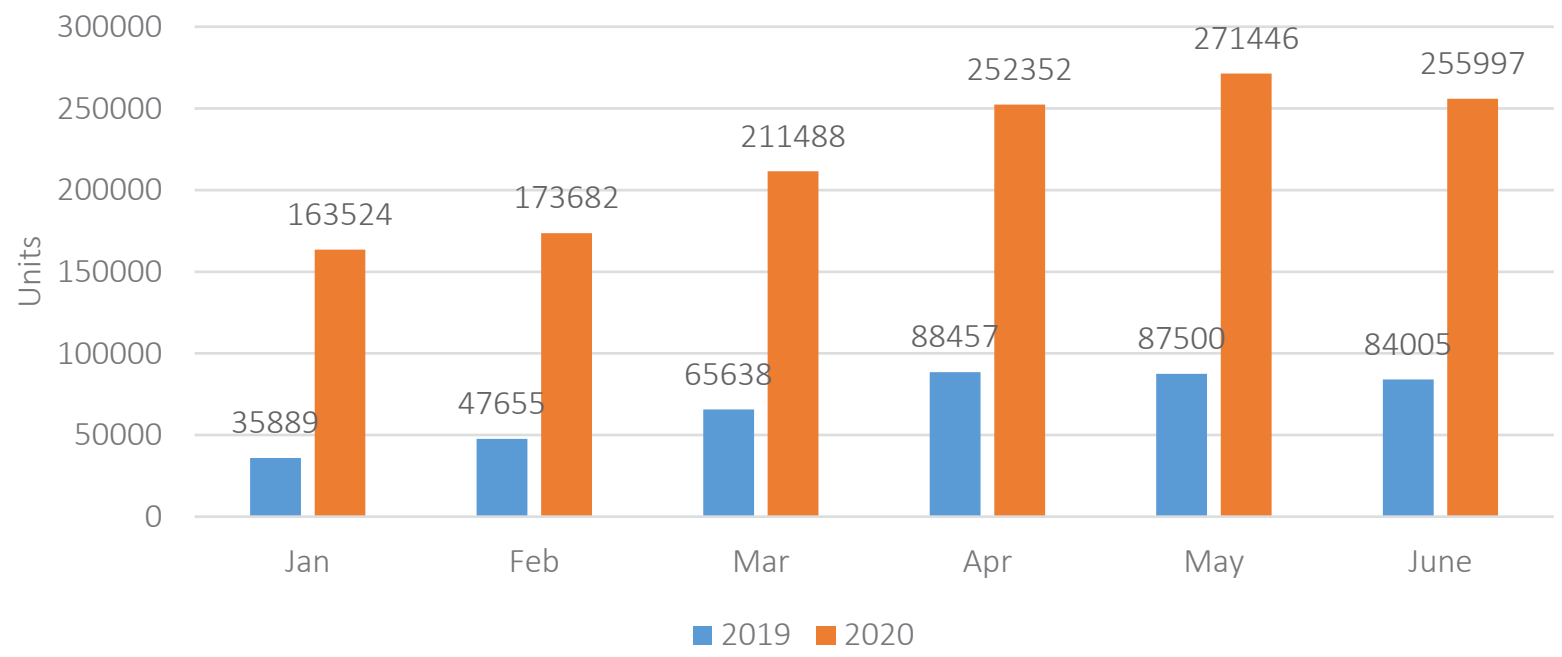

Figure 5. Dynamics of the number of electronic auto liability insurance policies in Ukraine for the first half of 2019-2020

What we currently observe in insurance industry is not even a crisis, but a transformation: the ways in which people and business interact are changing, but the principles of effective work in insurance market remain the same. For all service businesses the client is always the winner of the crisis, since low-quality services and providers at this time leave the market. Obviously, digitization puts pressure on all industries to personalize products or services and provide them on demand in real time on multiple platforms.

According to the survey of the expectations of Ukrainian insurance market participants during a pandemic and uncertainty results, only $14 \%$ of re- spondents admitted that the situation in their company has deteriorated over the past year, and $86 \%$ believe that it has improved or not changed (Figure 6).

The top five constraints for the insurance industry, according to survey findings, include quarantine (only 13.5\%), taxation, excessive regulation and outdated legislative framework of the industry (10.5\%), lack of motivation and career growth, low salary level (9.4\%), economic and political situation in the country and in the market, corruption (9.2\%), as well as low financial literacy (8.4\%). More than $15 \%$ of respondents believe that there are no factors that would hinder the development of the industry.

\section{$32.7 \%$}

Source: Forinsurer (2020a).

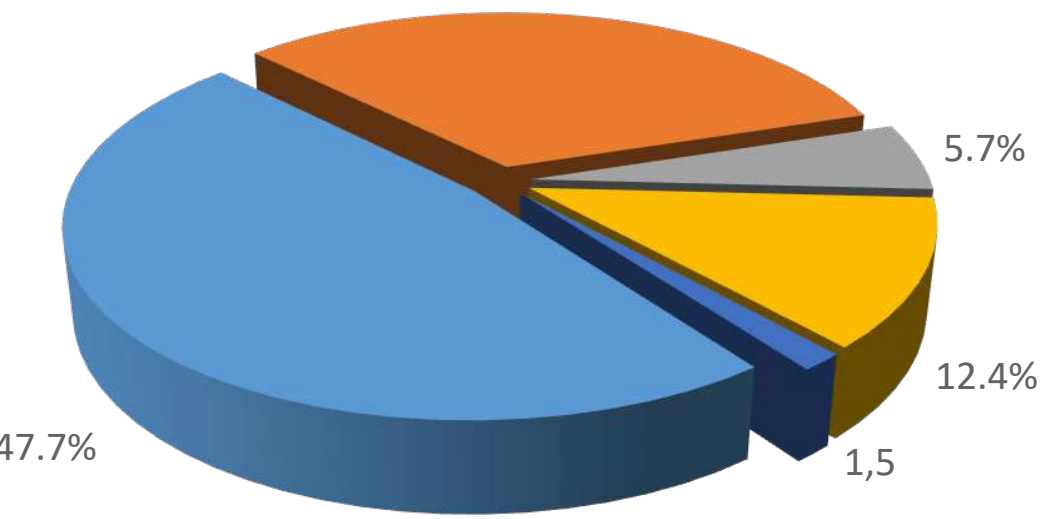

Not changed

Improved

Significantly improved

Worsened

Significantly worsened

Figure 6. Respondents' answers for the question "How the situation in your company has changed compared to the previous year?" 
Many insurance providers experienced significant revenue losses, but some managed to grow and the difference can be extreme. Although digital technology drives some companies to become clear market winners, for many more its impact depletes corporate earnings. For a long time, the traditional insurance business model has proved to be remarkably resilient to digital transformation, but due to pandemic it begins to acutely feel the digital effect: it is changing how services are delivered, and increasingly it is altering the nature of those services and even the business model itself.

We have identified four broad strategic directions that market participants have been developing in Ukraine: innovators insurers (striving to reshape the business processes through digitalization and innovations, these are usually insurers from TOP10), expansionists (focus on leveraging their capabilities, targeting new customer segments for existing products, or introducing new distribution channels to reach customer segments, not necessarily through innovations); followers (focus on scaling capabilities across a broad market after the introduction of digital innovations by leaders), survivors (who are slow to respond and focus on short-term performance and survival, are likely to leave the market soon).

\section{DISCUSSION}

The pandemic is leading to a shift from a hightouch to a low-touch economy, which related to low-touch interactions, safety measures, new human behaviors, and permanent industry shifts, offering opportunities for innovators. Depending on strategic choice, insurers can follow different business strategies to adopt and pivot in the low-touch economy: from keeping existing offering and clients to finding new ones, from copying solutions of other market players to creating innovations.

Most innovations in insurance industry today are focused on three main strategies:

- Make the policy purchase easier;

- Minimize price as much as possible;

- Engage the policyholder with tools and technologies.

These types of innovation around standalone product may help individual insurers grow market share innovating in the core of the company, but will do little to bridge the protection gap and reduce the numbers of the uninsured.

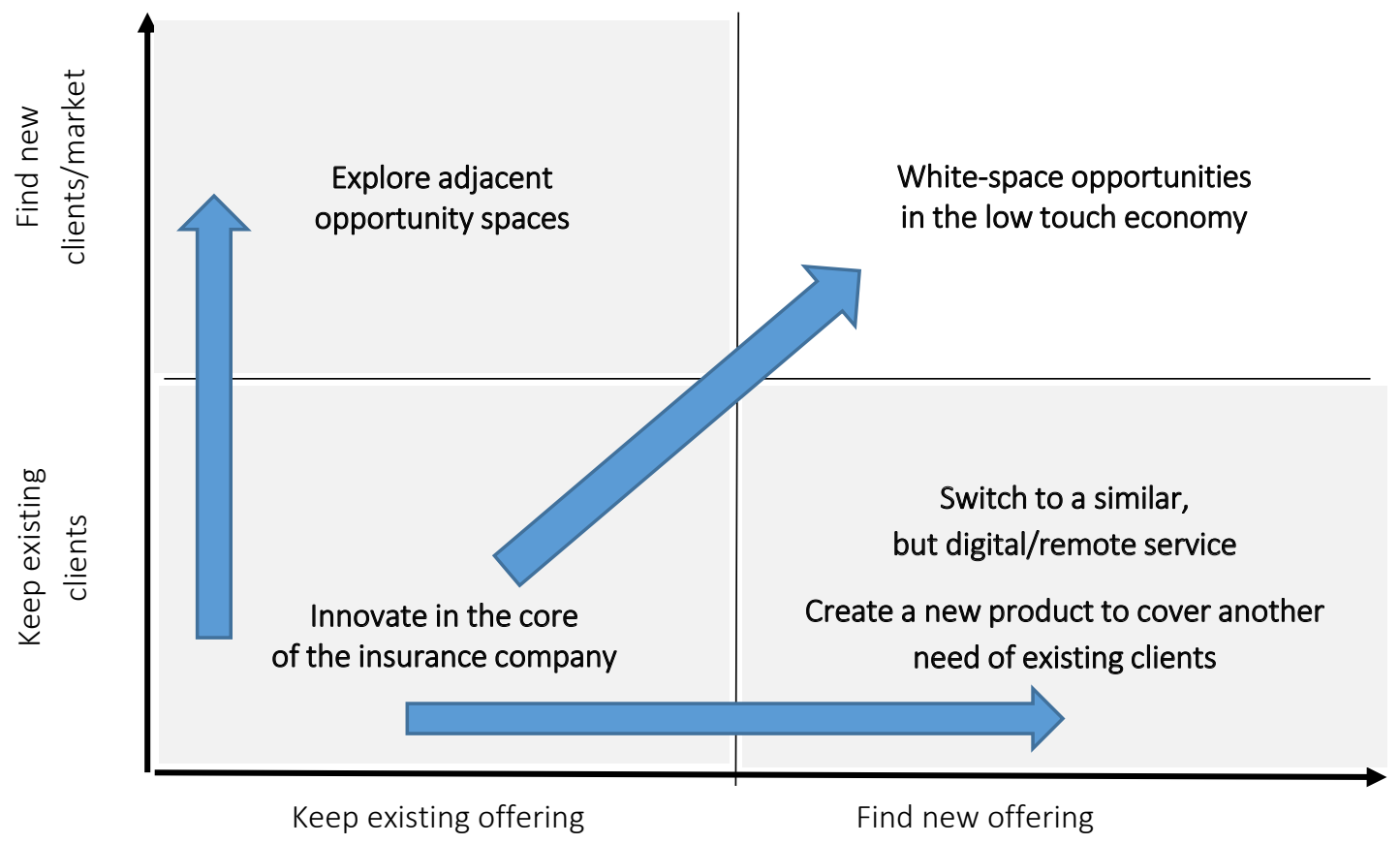

Figure 7. Opportunities for insurer carriers to adopt and pivot in the low-touch economy 
The pandemic provides further impetus for moving towards other grey squares (Figure 7) as well as for jumping to white-space opportunities which requires reshuffling of priorities in technology not only at the product level or at individual components of the value chain, but across the entire value chain. It will have a number of longterm (beneficial) effects on the industry.

Speaking of technology, the crisis is the spur to look at moving more systems and applications to the cloud. To be competitive in the modern market, insurers must adopt cloud native insurance platforms which enable the kinds of micro services and APIs.

The average consumer has become digitally savvy and expects a tailored experience. With data and tech improving every day, one-size-fitsall policies are a thing of the past. The insurers must focus on building greater trust and greater engagement with the customers.

There will be increased demand in some lines of commercial and personal insurance due to the Covid-19 pandemic, especially in the cyber security and health products, we are likely to see a rise in telehealth services, offering consultancy to patients via phone or online video services.

Subscription-based insurance is the next direction of industry development. While insurance is often a subscription-based business by its nature, due to a new wave of subscription economy growth (services such as Netflix and Amazon Prime), carriers would implement payment models which remove minimum policy lengths to make their offerings clearer, more useful, and more flexible. HSBC, meanwhile, has launched a flexible subscription service Select and Cover which likewise has no minimum term and offers up to seven kinds of insurance in one package (subscription) for a simple flat monthly fee. Customers should choose minimum three options, can add and remove one option during the year, and cancel coverage at any time without penalty.

The other key element of innovation is the ability to bundle multiple products and services into a single purchase which implies packaging up a suite of insurance products in a simple, comprehensible way. Research conducted by EIS Group (2020) shows that " $52 \%$ of respondents were interested in paying a flat monthly fee to cover a range of diverse insurance needs (including auto, home, and life and health), while $48 \%$ would like a configurable insurance bundles which they can adapt to their needs on-demand, with a simple on or off toggle for coverage" (p. 9). Combining covers can reduce the aggregated cost, thereby saving customers money when compared to purchasing individual policies.

The advent of open platforms and connected devices is also enabling innovative packaging of insurance and non-insurance products to add unique value. According to EISGroup (2020) study results, $58 \%$ of respondents were interested in a mobility bundle including auto insurance, auto loans, buying or leasing options, remote monitoring, maintenance and driver safety guidance, $55 \%$ were interested in an equivalent housing bundle.

Implementation of these innovations required a move from product-centric thinking, where each policy is a distinct sales line, to customer-centric thinking business models, where each person has a distinct set of needs which the insurer can meet.

Digital transformation also results in the emergence of insurtech alternative to traditional insurance. Mobile bank Monobank in Ukraine (retail product line of "Universal Bank" which emerged in cooperation with the Fintech Band) and digital insurer Mango Insurance (retail product line of Alfa-Group) are successful examples how tech companies are conquering the market, capturing the interest of younger consumers looking for a fairer alternative to traditional incumbents. $87 \%$ of American insurtech Lemonade consumers have never bought insurance for their homes before. Digital transformation allows new players to jump into the white space opportunities by covering the uninsured with new offerings. 


\section{CONCLUSION}

As COVID-19 spread across the globe, insurers were forced to adopt digital measures that would have under normal circumstances taken years to implement. Through the increase in communication channels, insurers can profit from the data access and create new analytical tools for pricing and underwriting. In the immediate term, insurers should leverage new technologies including automation, machine learning, which is currently used for customer service, fraud detection and the cloud to streamline the underwriting process and offer a seamless and efficient claims process. COVID-19 might be the catalyst for innovation in insurance, some far-reaching customer relationship changes. It is important for the Ukrainian insurance market that the result of these changes will be an increase in the number of the insured, insurance activity indicators such as market share, density, penetration.

Business strategies coming out of the crisis will make the sector look fundamentally different. While this crisis has brought many challenges, it also provided opportunities to come out of it stronger, more efficient and digitally enabled. COVID-19 is seen as a game-changer but in insurance it may rather reinforce existing trends, namely digitalization and customer-centric business models implementation.

\section{AUTHOR CONTRIBUTIONS}

Conceptualization: Oleksandra Shevchuk.

Data curation: Iryna Kondrat.

Formal analysis: Oleksandra Shevchuk, Jolanta Stanienda.

Investigation: Oleksandra Shevchuk.

Project administration: Iryna Kondrat.

Supervision: Oleksandra Shevchuk, Jolanta Stanienda.

Visualization: Iryna Kondrat, Jolanta Stanienda.

Writing - original draft: Oleksandra Shevchuk, Jolanta Stanienda.

Writing - review \& editing: Oleksandra Shevchuk, Iryna Kondrat.

\section{ACKNOWLEDGMENT}

This project was financed by the Ministry of Science and Higher Education of the Republic of Poland as part of the «Regional Initiative of Excellence" Programme for 2019-2022. Project No. 021/RID/2018/19. Total project budget: PLN 11897 131,40.

\section{REFERENCES}

1. Allianz. (2020). Allianz Global Insurance Report 2020: Skyfall. Retrieved from https://www. allianz.com/content/dam/onemarketing/azcom/Allianz_com/ economic-research/publications/ specials/en/2020/june/GlobalInsuranceReport_2020.pdf

2. Baber, H. (2020). Spillover Effect of COVID-19 on the Global Economyy-A review. Transnational Marketing Journal. Retrieved from https://papers.ssrn. com/sol3/papers.cfm?abstract_ id $=3717456$
3. Babuna, P., Yang, X., Gyilbag, A., Awudi, D. A., Ngmenbelle, D., \& Bian, D. (2020). The Impact of COVID-19 on the Insurance Industry. International Journal of Environmental Research and Public Healthh, 17, 5766. https:// doi.org/10.3390/ijerph17165766

4. Cappiello, A. (2020). The Digital (R)evolution of Insurance Business Models. American Journal of Economics and Business Administration, 12(1), 1-13. https://doi.org/10.3844/ ajebasp.2020.1.13
5. Danylyshyn, B. (2020). The peculiarities of economic crisis due to COVID-19 pandemic in a developing country: case of Ukraine. Problems and Perspectives in Management, 18(2), 13-22. https://doi. org/10.21511/ppm.18(2).2020.02

6. Ding, W., Levine, R., Lin, C., \& Xie, W. (2020). Corporate immunity to the COVID-19 pandemic (Working Paper 27055. National Bureau of Economic Research). https://doi. org/10.3386/w27055

7. EIS (2020). The Customer Compass Navigating the Future of Insurance. 
Retrieved from https://forinsurer. com/files/file00690.pdf

8. Forinsurer. (2019). Pidsumky diialnosti strakhovykh kompanii za I pivrichchia 2019 roku. [Results of insurance companies for the first half of 2019]. (In Ukrainian). Retrieved from https://forinsurer. com/files/file00665.pdf

9. Forinsurer. (2020a). Zarplaty $i$ predpochtenija rabotnikov strahovoj sfery Ukrainyv 2020 godu. Rezul'taty issledovanija [Salaries and preferences Ukraine's insurance sector employees in 2020. Research results]. (In Russian). Retrieved from https://forinsurer. com/files/file00686.pdf

10. Forinsurer. (2020b). Statistika strahovogo ryinka Ukrainyi. [Statistics of the insurance market of Ukraine]. (In Russian). Retrieved from https://forinsurer.com/ stat, $\% 20 \% 20$

11. Gasc, J. (2020). COVID-19: Six post-pandemic priorities facing insurers. Retrieved from https:// insuranceblog.accenture.com/ covid-19-six-post-pandemicpriorities-facing-insurers

12. Glonti, V., Trynchuk, V., Khovrak, I., Mokhonko G., Shkrobot, M., \& Manvelidze, L. (2020). Socialization of Organization Sustainable Development Based on the Principles of Corporate Social Responsibility. Montenegrin Journal of Economics, 16(1), 169-182. https://doi.org/10.14254/18005845/2020.16-1.11

13. Kaigorodova, G., Mustafina, A., Pyrkova, G., Vyukov, M., \& Davletshina, L. (2020). Cyber risks for insurance company. Advances in Intelligent Systems and Computing, 908, 669-677. Retrieved from https://www.eiopa.europa. eu/sites/default/files/publications/reports/eiopa_cyber_risk_ for_insurers_sept2019.pdf

14. Kirti, D., \& Shin, M. (2020). Impact of COVID-19 on Insurers. Retrieved from https://www.imf. org/ /media/Files/Publications/ covid19-special-notes/en-special-series-on-covid-19-impactof-covid-19-on-insurers.ashx
15. Lutsyshyn, Z., Klapkiv, Y., Kucher, T., \& Svirskyi, V. (2019). Development of innovative instruments in the financial market of Ukraine. Espacios, 40(28). Retrieved from https://www.researchgate.net/ publication/340819651_Development_of_innovative_instruments_in_the_financial_ market_of_Ukraine

16. Matteis, A. (2018). A "Starving" Policyholder: A New Approach to the Old Problem of Innovation. Retrieved from https://www. rgare.com/knowledge-center/ media/articles/a-starving-policyholder-a-new-approach-to-theold-problem-of-innovation

17. Mey, N., \& Ridder, P. (2020). Report The new Low Touch Economy. How to navigate the world after Covid-19. Retrieved from https://info.boardofinnovation. com/hubfs/Innovate\%20low\%20 touch\%20economy.pdf

18. Mtsbu. (2020). Za 6 misiatsiv $2020 \mathrm{r}$. ukladeno bilshe $1,3 \mathrm{mln}$. elektronnykh dohovoriv OSCPV. [For 6 months of 2020 signed more than 1.3 million. electronic auto liability insurance policies]. (In Ukrainian). Retrieved from http://www.mtsbu.ua/ua/presscenter/news/158803

19. Mustafina, A., Kaigorodova, G., Alyakina, P., Velichko, N., \& Zainullina, M. (2020). Digital technology in insurance. Advances in Intelligent Systems and Computing, 908, 678-685.

20. National Bank of Ukraine. (2020a). COVID-19 pomirno vplynuv na strakhovykiv, prote istotno poznachyvsia na kredytuvanni nebankivskymy ustanovamy - zvitnist za pershe pivrichchia 2020. [COVID-19 had a moderate impact on insurers, but significantly affected lending by non-banking institutions - reporting for the first half of 2020]. (In Ukrainian). Retrieved from https://bank.gov.ua/ua/news/ all/covid-19-pomirno-vplinuvna-strahovikiv-prote-istotnopoznachivsya-na-kredituvanninebankivskimi-ustanovami-zvitnist-za-pershe-pivrichchya- 2020
21. National Bank of Ukraine. (2020b). Ogljad nebankivs'kogo finansovogo sektoru (gruden' 2020). [Review of the non-banking financial sector (December 2020)]. (In Ukrainian). Retrieved from https://bank.gov.ua/admin_uploads/article/Nonbanking_Sector_Review_2020-12. $\mathrm{pdf} ? \mathrm{v}=4$

22. National Bank of Ukraine. (2020c). Ofitsiinyi kurs hryvni shchodo inozemnykh valiut. [The official exchange rate of hryvnia against foreign currencies]. (In Ukrainian). Retrieved from https://bank.gov.ua/ua/markets/ exchangerates

23. Oliinyk, V., \& Kozmenko, O. (2019). Optimization of investment portfolio management. Serbian Journal of Management, 14(2), 373-387. Retrieved from https://search.proquest. com/openview/7e0aa4563925 bd860b5faa040d0842a3/1?pqorigsite $=$ gscholar $\& \mathrm{cbl}=4464512$

24. Polinkevych, O., Khovrak, I., Trynchuk, V., Klapkiv, Y., \& Volynets, I. (2020). Business Risk Management in Times of Crises and Pandemics. Montenegrin Journal of Economics, 17(3), 117-128.

25. PwC (2020). Insurance 2020: Turning change into opportunity. Retrieved from https://www. pwc.com/gx/en/insurance/pdf/ insurance-2020-turning-changeinto-opportunity.pdf

26. Richter, A., \& Wilson, T. (2020). Covid-19: implications for insurer risk management and the insurability of pandemic risk. The Geneva Risk and Insurance Review, 45, 171-199. https://doi. org/10.1057/s10713-020-00054-Z

27. Shkolnyk, I., Kozmenko, S., Polach, J., \& Wolanin, E. (2020). State financial security: Comprehensive analysis of its impact factors. Journal of International Studies, 13(2), 291-309. Retrieved from https:// www.researchgate.net/publication/342710391_State_financial_ security_Comprehensive_analysis_of_its_impact_factors 
28. Siddiqui, T., Ahmed, H., \& Naushad, M. (2020). Diffusion of COVID-19 impact across selected stock markets: a wavelet coherency analysis. Investment Management and Financial Innovations, 17(4), 202-214. https://doi.org/10.21511/ imfi.17(4).2020.19

29. Tandon, A., Roubal, T., McDonald, L., Cowley, P., Palu, T., Cruz, V., Eozenou P., Cain, J., Teo, H., Schmidt, M., Pambudi, E., Postolovska, I., Evans, D., \& Kurowski, C. (2020). Economic Impact of COVID-19. Implications for Health Financing in Asia and Pacific (Discussion paper. World Bank Group). http:// dx.doi.org/10.1596/34572
30. Vinogradova, E., Tsvetkova, L., \& Orlaniuk-Malitskaia, L. (2019). Development of the risk insurance zone for high-tech enterprises. International Journal of Management and Business Research, 9(2), 138-148. Retrieved from http://converis.misis.ru/ converis/portal/Publication/105 50421 ; jsessionid $=e e 724 \mathrm{a} 8579 \mathrm{e} 4 \mathrm{~b}$ e86811572791874?lang=en_GB

31. Vnukova, N., Kavun, S., Kolodiziev, O., Achkasova, S., \& Hontar, D. (2020). Indicatorsmarkers for assessment of probability of insurance companies' relatedness in implementation of riskoriented approach. Ikonomicheski Izsledvania, 1, 151-173. Retrieved from https:// ideas.repec.org/a/bas/econst/ y2020i1p151-173.html

32. Wu, D., \& Olson, D. (2020) The Effect of COVID-19 on the Banking Sector. Modelling the Impact of COVID-19. In Pandemic Risk Management in Operations and Finance. Springer, Cham. https://doi. org/10.1007/978-3-030-521974_8

33. Yehorycheva, S., Fysun, I., Hudz, T., Palchuk, O., \& Boiko, N. (2020). Innovations in the insurance market of a developing country: Case of Ukraine. Investment Management and Financial Innovations, 17(4), 175188. https://doi.org/10.21511/ imfi.17(4).2020.17 